\title{
EFEKTIFITAS PENGGUNAAN NAUNGAN TERHADAP PERKECAMBAHAN BENIH KOPI ROBUSTA
}

\author{
Windy Manullang \\ Politeknik Pembangunan Pertanian Medan, Jl. Binjai Km. 10 Medan, Sumatera Utara, Indonesia
}

Koresponden Email: manullangwindy2017@gmail.com

\begin{abstract}
Abstrak
Salah satu faktor yang mempengaruhi performa perkecambahan benih adalah faktor lingkungan. Penelitian ini bertujuan untuk melihat pengaruh faktor lingkungan yaitu intensitas cahaya terhadap daya berkecambah dan perkembangan kecambah kopi robusta (Coffea canephora) untuk mengetahui intensitas naungan yang optimal untuk persemaian benih kopi. Penelitian ini dilakukan di lahan Teaching Factory Polbangtan Medan. Rancangan penelitian yang digunakan adalah Rancangan Acak Lengkap Non Faktorial. Perlakuan penelitian adalah naungan dengan tingkat level yang berbeda-beda, yaitu N1 = Tanpa Naungan, N2 = Naungan paranet $75 \%$ dan N3 = Naungan $100 \%$ (atap seng). Ulangan yang dilakukan adalah masing-masing perlakuan dilakukan sebanyak 4 ulangan dengan 50 populasi/ulangan. Pengamatan yang dilakukan yaitu: Persentase perkecambahan (\%), tinggi kecambah, panjang akar, lama hari berkecambah, persentase keseragaman pertumbuhan, dan indeks vigor. Berdasarkan hasil penelitian didapatkan bahwa persentase perkecambahan (\%), panjang akar, lama hari berkecambah, persentase keseragaman pertumbuhan, dan indeks vigor tertinggi pada perlakuan N3, dimana tinggi kecambah berbeda nyata pada setiap perlakuannya.
\end{abstract}

Kata Kunci: Perkecambahan, Naungan, Kopi Robusta

\begin{abstract}
One of the factors that affect seed germination performance is environmental factor. In this study, we investigated the effect of environmental factors, namely light intensity on the germination and development of robusta coffee (Coffea canephora) sprouts to determine the optimal shade intensity for coffee seed nurseries. This research was conducted at the Teaching Factory Polbangtan Medan. The research design used was a completely randomized non-factorial design. The treatment in this study was shade with different levels, namely N1 = No Shade, $N 2=75 \%$ Paranet Shade and N3 $=100 \%$ Shade (zinc roof). The replications carried out were each treatment carried out as many as 4 replications with 50 populations/replication.. Observations were made: Percentage of germination (\%), germination height, root length, length of germination day, percentage of growth uniformity, and vigor index. Based on the results of the study, it was found that the percentage of germination (\%), root length, days of germination, percentage of growth uniformity, and vigor index were highest in treatment N3, where the height of sprouts was significantly different in each treatment.
\end{abstract}

Keywords : Germination, Shade, Robusta Coffee

\section{PENDAHULUAN}

Kopi (Coffea spp.) merupakan salah satu komoditas ekspor penting pada subsektor perkebunan di Indonesia. Tanaman kopi merupakan salah satu komoditi perkebunan yang memiliki nilai ekonomis cukup tinggi diantara tanaman perkebunan lainnya dan sebagai penyumbang sumber devisa negara. Kopi juga merupakan sumber pendapatan bagi lebih dari satu setengah juta jiwa petani kopi di Indonesia [1]. Pada tahun 2019, luas areal perkebunan kopi di Indonesia mencapai $1.260 .000 \mathrm{Ha}$ dengan produksi mencapai 760.960 Ton dan komposisi kepemilikan kopi Indonesia sebesar 95,45\% dari luas areal perkebunan kopi tersebut adalah perkebunan rakyat (PR) sementara sisanya diusahakan oleh perkebunan besar milik swasta (PBS) sebesar 2,44\%, dan perkebunan besar milik negara (PBN) sebesar 2,21\%. Keadaan tersebut menunjukkan posisi dari peranan petani kopi dalam perekonomian nasional cukup signifikan. Dengan demikian secara langsung keberhasilan perkopian Indonesia akan mensejahterahkan petani [2].

Permintaan kopi yang tinggi tidak disertai peningkatan produksi kopi. Produktivitas tanaman kopi yang rendah disebabkan oleh beberapa hal. Salah satunya adalah pengelolaan tanaman yang kurang tepat pada saat pembibitan. Pada tahap pembibitan, sering 
didapati hal-hal yang kurang tepat, yaitu: penggunaan media tanam yang tidak cocok untuk perkecambahan dan pertumbuhan bibit, kedalaman benih yang tidak tepat, dan penggunaan naungan serta penyiraman yang tidak memadai atau berlebihan selama periode pembibitan [3].

Kopi termasuk tanaman C3, memerlukan intensitas cahaya yang tidak penuh dalam melakukan proses fotosintesis. Intensitas cahaya yang dibutuhkan pada tanaman kopi berbeda beda pada tiap fasenya. Tingkat naungan yang tidak sesuai pada fase vegetatif dan generatif akan mempengaruhi pertumbuhan, produksi dan cita rasa kopi. Naungan umumnya dibutuhkan oleh tanaman golongan $\mathrm{C} 3$ dan tanaman yang berada pada fase pembibitan. Untuk tanaman C3, naungan diperlukan pada sepanjang hidup tanaman. Naungan berfungsi untuk mendapatkan cahaya yang optimal bagi tanaman yang dinaungi sehingga tanaman tidak mengalami kematian akibat mendapatkan cahaya yang terlalu tinggi [4].

Banyak penelitian yang telah mengkaji pengaruh naungan terhadap pertumbuhan bibit kopi setelah fase perkecambahan, namun kualitas dan pertumbuhan bibit sudah dimulai bahkan dari fase pengumpulan dan penanganan bibit sebelum perkecambahan. Pengelolaan benih pra-tanam mencakup semua operasi yang melibatkan pengumpulan, persiapan dan penanganan benih, dan perawatan benih praperkecambahan [3].

Tujuan dari penelitian ini adalah untuk mengetahui pengaruh naungan pada persemaian biji kopi robusta, yaitu terhadap persentase perkecambahan (\%), tinggi kecambah, panjang akar, lama hari berkecambah, persentase keseragaman pertumbuhan, dan indeks vigor.

\section{MATERIAL DAN METODE}

\section{Waktu dan Tempat}

Kegiatan penelitian telah dilaksanakan pada Bulan Juli - Agustus 2018 di Lahan Praktek Jurusan Penyuluhan Perkebunan Politeknik Pembagunan Pertanian Medan Jl. Binjai Km 10 Kecamatan Sunggal Kabupaten Deli Serdang. Tinggi tempat dari permukaan laut \pm 25 meter dan suhu rata-rata $30-35^{\circ} \mathrm{C}$.

\section{Bahan dan Alat}

Bahan yang yang digunakan adalah kopi jenis Robusta Klon BP 358 dari Pusat Penelitian Kopi dan Kakao di Jember. Media tanam yang digunakan pada penelitian ini adalah Topsoil dan Pasir.

\section{Perlakuan dan Analisis Data Penelitian}

Perlakuan Dalam Penelitian adalah naungan dengan tingakt level yang berbedabeda, yaitu N1 = Tanpa Naungan, N2 = Naungan paranet $75 \%$, N3 = Naungan $100 \%$ (atap seng). Ulangan sebanyak 4 kali dengan 50 populasi/ulangan dan 20 sampel diambil setiap ulangan. Rancangan penelitian yang digunakan dalam penelitian ini adalah Rancangan Acak Lengkap Non Faktorial, karena lingkungan dianggap homogen. Pengacakan digunakan secara Simple Random Sampling. Adapun model persamaannya adalah sebagai berikut:

$Y_{i j k}=\mu+r_{i}+\varepsilon_{i j} \ldots$ Pers (1)

$\mathrm{Y}_{\mathrm{ijk}}=$ nilai pengamatan pada perlakuan ke- $\mathrm{i}$ dan ulangan ke-j

$\mu=$ nilai tengah umum

$\tau_{\mathrm{i}}=$ pengaruh perlakuan ke-i

$\varepsilon_{\mathrm{ij}}=$ galat percobaan pada perlakuan ke-i dan ulangan ke-j

Pengamatan yang dilakukan yaitu: Persentase perkecambahan (\%), tinggi kecambah, panjang akar, lama hari berkecambah, persentase keseragaman pertumbuhan, dan indeks vigor

\section{Pelaksanaan Penelitian}

Persiapan Biji

Benih berasal dari Pusat Penelitian Kopi dan Kakao Indonesia (Puslitkoka) Jember dengan klon BP 358. Untuk menentukan benih yang baik, biji kopi dimasukkan kedalam air, biji yang tenggelam merupakan biji yang telah digunakan sebagai benih, sedangkan biji yang mengapung merupakan biji yang tidak layak digunakan. Biji yang seragam dijadikan sebagai bahan penelitian.

\section{Persiapan Media Kecambah}

Media perkecambahan yang digunakan dalam penelitian ini yaitu top soil dan pasir. Sebelum media pasir digunakan, terlebih dahulu disterilkan dengan menyangrai pasir selama 15 menit. Hal ini bertujuan agar media pasir yang akan digunakan terhindar dari mikroorganisme. 
Info Artikel

\section{Persiapan naungan}

Lahan untuk naungan dibersihkan hingga bebas dari nematoda parasit dan cendawan akar, kemudian dibagi menjadi tiga unit persegi yang dibuat arah Utara-Selatan. Lebar naungan 120 $\mathrm{cm}$ dan panjangnya $200 \mathrm{~cm}$. Untuk tinggi naungan, arah timur $180 \mathrm{~cm}$ dan arah barat 120 $\mathrm{cm}$. Tanah dicangkul kemudian dibersihkan dari sisa-sisa akar dan rumput. Bedengan ditinggikan $\pm 20 \mathrm{~cm}$ menggunakan tanah subur dan gembur, di atasnya ditambah lapisan pasir halus setebal 5 $\mathrm{cm}$. Pinggirnya diberi penahan dari bata merah agar tanah tidak longsor. Untuk mencegah nematoda parasit, dilakukan fumigasi dengan Vapam $100 \mathrm{ml} / 10 \mathrm{lt}$ air untuk setiap $\mathrm{m}^{2}$ bedengan. Bedengan ditutup plastik selama 7 hari, kemudian benih disemaikan. Bedengan diberi atap/naungan sesuai perlakuan yaitu N1: Tanpa naungan (Tanpa paranet), N2: $75 \%$ (naungan paranet $75 \%$ ), dan N3: Naungan 100 $\%$ (seng).

\section{Penyemaian kecambah}

Benih kopi yang telah diberikan perlakuan siap untuk disemai. Benih kopi 10 disusun dengan jarak $5 \mathrm{~cm}$ antar benih. Posisi bagian mata tunas menghadap ke atas.

\section{Parameter Pengamatan}

Persentase kecambah

Persentase kecambah menunjukkan jumlah kecambah normal yang dihasilkan oleh benih murni pada kondisi lingkungan tertentu dalam jangka waktu yang telah ditetapkan. Presentase kecambah dihitung pada saat berumur 30 hari setelah semai (HSS). Menurut [5] cara menghitung persentase perkecambahan yaitu sebagai berikut:

$P K=\frac{\text { Jumlah biji berkecambah }}{\text { Jumlah biji yang disemai }} \times 100 \%$...Pers. $(2)$

\section{Laju perkecambahan}

Laju perkecambahan dihitung dengan menghitung dari waktu munculnya plumula benih dari awal berkecambah sampai akhir. Menurut [6] cara untuk menghitung laju perkecambahan adalah sebagai berikut:

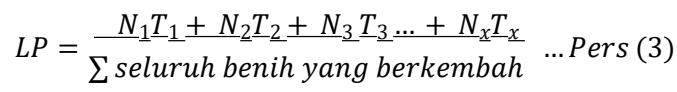

Keterangan:

LP $=$ Laju Perkecambahan

$\mathrm{N}=$ Jumlah benih yang berkecambah

DOI: https://doi.org/10.55127/ae.v15i2.102 setiap hari

$\mathrm{T}=$ Jumlah waktu antara awal pengujian sampai dengan akhir dari interval tertentu suatu pengamatan

\section{Indeks vigor}

Indeks vigor dihitung dengan menghitung hari yang diperlukan untuk berkecambah dengan banyaknya jumlah benih yang berkecambah. Menurut [6], bahwa indeks vigor dihitung dengan menggunakan rumus dibawah ini :

$I V=\frac{D 1}{G 1}+\frac{D 2}{G 2}+\frac{D 3}{G 3}+\cdots \frac{D n}{G n} \ldots \operatorname{Pers}(4)$

dimana;

$\mathrm{IV}=$ Indeks Vigor

$\mathrm{G}=$ Jumlah benih yang berkecambah pada hari tertentu

$\mathrm{D}=$ Waktu yang bersesuaian dengan jumlah tersebut

$=$ Jumlah hari pada perhitungan terakhir

\section{Panjang akar (cm)}

Panjang akar (radikula) diukur dari leher akar sampai ujung akar. Pengukuran dilakukan pada saat benih berumur 35 hari setelah semai (HSS).

\section{Tinggi benih (cm)}

Tinggi benih diukur dari permukaan tanah sampai titik tumbuh. Pengukuran tinggi benih dengan menggunakan mistar. Tinggi benih diukur pada saat tanaman berumur $40 \mathrm{HSS}$.

\section{Analisis data}

Data yang terkumpul dari hasil penelitian dianalisis dengan Tabel sidik ragam untuk menguji pengaruh nyata perlakuan. Bila $\mathrm{F}$ hitung $>\mathrm{F}$ tabel dengan $\alpha=5 \%$, maka terdapat pengaruh pengaruh nyata dan bila $\mathrm{F}$ hitung $>\mathrm{F}$ tabel dengan $\alpha=1 \%$, maka terdapat pengaruh sangat nyata. Selanjutnya untu membandingkan rata-rata perlakuan, digunakan $\mathrm{Uji}$ Duncan dengan taraf $\alpha=5 \%$.

\section{HASIL DAN PEMBAHASAN Persentase Perkecambahan}

Berdasarkan hasil sidik ragam, tingkat persentase perkecambahan dengan perlakuan tingkat naungan menunjukkan perbedaan tidak nyata pada perlakuan tingkat naungan $75 \%$ (N2) dan $100 \%(\mathrm{~N} 3)$, namun keduanya memiliki perbedaan nyata terhadap perlakuan tanpa 
naungan (N1). Hasil penelitian pengaruh tingkat naungan terhadap persentase perkecambahan dapat dilihat pada Tabel 1.

Tabel 1. Pengaruh Tingkat Naungan Terhadap Persentase Perkecambahan (\%)

\begin{tabular}{lc}
\hline \multicolumn{1}{c}{ Tingkat Naungan } & $\begin{array}{c}\text { Persen perkecambahan } \\
(\%)\end{array}$ \\
\cline { 2 - 2 } $\begin{array}{l}\text { Tanpa Naungan (N1) } \\
\text { Tingkat Naungan } 75 \%\end{array}$ & $16.25 \mathrm{~b}$ \\
(N2) & $85 \mathrm{a}$ \\
Tingkat Naungan & \\
$100 \%$ (N3) & $92.5 \mathrm{a}$ \\
\hline $\begin{array}{l}\text { Ket : Angka rata-rata yang diikuti oleh huruf yang } \\
\text { sama berarti menunjukkan tidak berbeda nyata } \\
\text { pada uji Duncan taraf 5\% }\end{array}$
\end{tabular}

Dari data yang diperoleh didapatkan bahwa tingkat naungan $100 \%$ (N3) memberikan hasil yang tertinggi pada persentase perkecambahan benih kopi dengan selisih perbedaan $7.5 \%$ dengan N2 (naungan 75\%). Namun hasil sidik ragam persentase perkecambahan pada kedua tingkat naungan tersebut menunjukkan perbedaan tidak nyata, hal ini sesuai dengan pernyataan [7] bahwa benih dapat berkecambah lebih dari satu macam rentang intensitas cahaya. Dalam hal ini seluruh perlakuan mendapatkan penyiram yang sama setiap harinya, tercatat bahwa saat penelitian adalah musim kemarau dimana hari hujan sedikit.

Dari hasil pengamatan pengaruh tingkat naungan terhadap persentase perkecambahan dapat dilihat bahwa intensitas naungan berpengaruh terhadap perkecambahan biji kopi selama fase pertumbuhannya terutama pada fase pembibitan. Fase pembibitan lebih banyak membutuhkan intensitas naungan yang tinggi dibandingkan fase dewasa. Persemaian biji kopi di bawah intensitas cahaya $100 \%$ dan langit terbuka, benih akan segera mati setelah muncul. Ha ini menunjukkan bahwa spesies ini membutuhkan naungan selama pertumbuhan awal.

\section{Tinggi Kecambah (cm)}

Berdasarkan hasil sidik ragam, diperoleh bahwa pengaruh perlakuan tingkat naungan terhadap tinggi kecambah berbeda nyata antara ketiga perlakuan. Hasil penelitian pengaruh tingkat naungan terhadap tinggi kecambah dapat dilihat pada Tabel 2.
Tabel 2. Pengaruh Tingkat Naungan Terhadap Tinggi Kecambah $(\mathrm{cm})$

\begin{tabular}{|c|c|}
\hline Tingkat Naungan & $\begin{array}{c}\text { Tinggi } \\
\text { Kecambah }(\mathrm{cm})\end{array}$ \\
\hline Tanpa Naungan (N1) & $0.65 c$ \\
\hline $\begin{array}{l}\text { Tingkat Naungan } 75 \% \\
\text { (N2) }\end{array}$ & $6.51 b$ \\
\hline $\begin{array}{l}\text { Tingkat Naungan } 100 \% \\
\text { (N3) }\end{array}$ & $8.41 \mathrm{a}$ \\
\hline
\end{tabular}

Berdasarkan Tabel 2, dapat dilihat bahwa tingkat naungan $100 \%(\mathrm{~N} 3)$ berbeda nyata dengan N2 (naungan 75\%). Dimana N3 memberikan tinggi kecambah tertinggi yaitu $8.41 \mathrm{~cm}$. Dari data ini terlihat bahwa perlakuan tingkat naungan $100 \%$ memberikan manfaat dalam hal menjaga kelembaban tanah dan udara sehingga mengoptimalkan penyerapan air yang efisien pada perkecambahan. Hal ini sesuai dengan pernyataan [8] yang menyatakan bahwa penyerapan air dan unsur hara yang cukup oleh tanaman menyebabkan pertumbuhan tanaman menjadi lebih baik, yang ditunjukkan dengan pertumbuhan tinggi tanaman yang optimal. Tinggi kecambah untuk tiap perlakuan dapat dilihat pada Gambar 1.

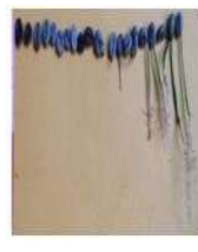

N1

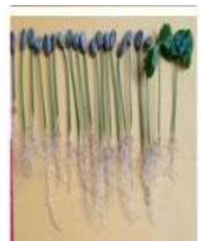

N2

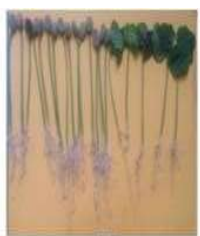

N3
Gambar 1. Kecambah Kopi Robusta

\section{Panjang Akar (cm)}

Berdasarkan hasil sidik ragam panjang akar dengan perlakuan tingkat naungan menunjukkan perbedaan yang tidak nyata pada perlakuan tingkat naungan $100 \%$. Hasil penelitian pengaruh tingkat naugan terhadap panjang akar dapat dilihat pada Tabel 3.

Dari Tabel 3, dapat dilihat bahwa panjang akar pada perlakuan tingkat naungan $100 \%(\mathrm{~N} 3)$ tidak berbeda nyata dengan N2 (naungan 75\%). Dimana N3 memberikan rataan tinggi kecambah tertinggi yaitu $5,09 \mathrm{~cm}$. Dari pengamatan ini terlihat bahwa naungan tingkat naungan $100 \%$ memberikan manfaat dalam hal 
menjaga kelembaban tanah dan udara sehingga mengoptimalkan penyerapan air yang efisien pada perkecambahan. Hal ini sejalan dengan pernyataan [9] bahwa naungan dapat memberikan sejumlah manfaat penting untuk kopi. Fungsi naungan telah ditemukan mampu mengurangi suhu udara, tanah, dan suhu permukaan daun serta amplitudo termal. Hal ini juga melindungi tanaman kopi dari yang kuat angin, hujan, dan mengurangi efek bantalan dua tahunan, dan meningkatkan dan mempertahankan kesuburan tanah.

Tabel 3. Pengaruh Tingkat Naungan terhadap Panjang Akar (cm)

\begin{tabular}{lc}
\hline \multicolumn{1}{c}{ Tingkat Naungan } & $\begin{array}{c}\text { Rataan Panjang Akar } \\
(\mathrm{cm})\end{array}$ \\
\cline { 2 - 2 } $\begin{array}{l}\text { Tanpa Naungan (N1) } \\
\text { Tingkat Naungan }\end{array}$ & $0.5 \mathrm{~b}$ \\
$75 \%(\mathrm{~N} 2)$ & $4.93 \mathrm{a}$ \\
Tingkat Naungan & $5.09 \mathrm{a}$ \\
$100 \%(\mathrm{~N} 3)$ & \\
\hline $\begin{array}{l}\text { Ket : Angka rata-rata yang diikuti oleh huruf yang } \\
\text { sama berarti menunjukkan tidak berbeda nyata } \\
\text { pada uji Duncan taraf 5\% }\end{array}$
\end{tabular}

\section{Lama Hari Berkecambah (Hari)}

Berdasarkan data pengamatan lama hari berkecambah, diperoleh bahwa pada perlakuan tingkat naungan $100 \%$ (N3) menunjukkan persentase jumlah benih berkecambah yang tertinggi hingga mencapai $88,75 \%$ pada 30 HSS. Hasil penelitian pengaruh tingkat naungan terhadap lama hari berkecambah dapat dilihat pada Tabel 4.

Tabel 4. Pengaruh Tingkat Naungan terhadap Lama Hari Berkecambah (Hari)

\begin{tabular}{|c|c|c|c|}
\hline \multirow{2}{*}{$\begin{array}{l}\text { Tingkat } \\
\text { Naungan }\end{array}$} & \multicolumn{3}{|c|}{$\begin{array}{l}\text { Lama Hari Berkecambah } \\
\text { (Hari) }\end{array}$} \\
\hline & $30 \mathrm{HSS}$ & $35 \mathrm{HSS}$ & $40 \mathrm{HSS}$ \\
\hline $\begin{array}{l}\text { Tanpa } \\
\text { Naungan (N1) }\end{array}$ & $11,25 \%$ & $5 \%$ & 0 \\
\hline $\begin{array}{l}\text { Tingkat } \\
\text { Naungan } 75 \% \\
\text { (N2) }\end{array}$ & $75 \%$ & $10 \%$ & 0 \\
\hline $\begin{array}{l}\text { Tingkat } \\
\text { Naungan } \\
100 \%(\mathrm{~N} 3)\end{array}$ & $88,75 \%$ & $3,75 \%$ & 0 \\
\hline
\end{tabular}

Dari data pengamatan penelitian diperoleh bahwa kopi robusta berkecambah di umur 30 hari. Di lapangan tercatat bahwa di hari ke- 28

DOI: https://doi.org/10.55127/ae.v15i2.102 setelah semai beberapa biji mulai berkecambah. Namun terlihat bahwa di hari ke-30 kecambah dalam jumlah besar mengeluarkan kotiledonnya hingga pertumbuhan kecambah terlama pada hari ke-35. Peneliti mencoba mengamati hingga hari ke-40 dengan tetap melakukan penyiraman yang rutin setiap harinya, namun didapati tidak ada lagi penambahan jumlah benih yang berkecambah. Hal ini diduga oleh tingkat suhu pada perlakuan naungan 100\% (M3) menjaga kelembaban air di media persemaian sehingga merangsang hormon Giberelin yang mampu merangsang pertumbuhan embrio. Hal ini sesuai dengan pernyataan [5] yang menyatakan bahwa diduga Giberelin yang terdapat di dalam biji merupakan penghubung antara isyarat lingkungan dan proses metabolik yang menyebabkan pertumbuhan embrio. Sebagai contoh, air yang tersedia dalam jumlah cukup akan menyebabkan embrio pada biji rumput rumputan mengeluarkan Giberelin yang mendorong perkecambahan dengan memanfaatkan cadangan makanan yang terdapat di dalam biji

\section{Indeks Vigor}

Berdasarkan hasil sidik ragam lama indeks vigor dengan perlakuan N3 menunjukkan perbedaan yang tidak nyata dengan perlakuan tingkat naungan N2. Hasil penelitian pengaruh tingkat naugan terhadap indeks vigor dapat dilihat pada Tabel 5 di bawah ini.

Tabel 5. Pengaruh Tingkat Naungan terhadap Indeks vigor

\begin{tabular}{lc}
\hline Tingkat Naungan & $\begin{array}{c}\text { Indeks Vigor } \\
(\%)\end{array}$ \\
\hline Tanpa Naungan (N1) & $0.08 \mathrm{~b}$ \\
Tingkat Naungan $75 \%(\mathrm{~N} 2)$ & $1.14 \mathrm{a}$ \\
Tingkat Naungan $100 \%(\mathrm{~N} 3)$ & $1.22 \mathrm{a}$ \\
\hline Ket : Angka rata-rata yang diikuti oleh huruf yang \\
$\quad$ sama berarti menunjukkan tidak berbeda nyata \\
pada uji Duncan taraf $5 \%$
\end{tabular}

Dari data yang diperoleh didapatkan bahwa tingkat naungan $100 \%$ (N3) memberikan hasil yang tertinggi pada indeks vigor benih kopi dengan nilai $1.22 \%$. Meskipun indeks vigor benih kopi di bawah naungan intensitas cahaya $75 \%$ memiliki parameter pertumbuhan indeks vigor yang sebanding secara statistik, pertumbuhan terbaik dan bibit paling stabil secara keseluruhan diperoleh di bawah naungan 
Info Artikel

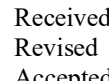

25 November 2021

27 Desember 2021

: 28 Desember 2021
Jurnal Agrica Ekstensia

Vol. 15 No. 2 Tahun 2021

p-ISSN

e-ISSN intensitas $100 \%$ Hal ini diduga adanya penghambatan efek dari cahaya selama proses biji berkecambah. Hal ini sesuai dengan pernyataan [10] mengamati bahwa biji kopi sensitif terhadap cahaya putih, yang memperlambat perkecambahan biji. Sejak cahaya penyebab induksi dari GAbiosintesis di biji [11], cahaya dapat menginduksi peningkatan di GA dalam biji kopi. Akibatnya, jumlah GA endogen yang diinduksi oleh cahaya lebih dari jumlah yang dibutuhkan untuk perkecambahan dan kelebihannya menjadi racun, mempengaruhi perkecambahan yang menyebabkan penundaannya [8]. Signifikansi ekologi dari efek penghambatan cahaya selama perkecambahan biji kopi disarankan oleh [10] . Kopi pada awalnya diklasifikasikan sebagai tanaman peneduh [12].

\section{Keseragaman Pertumbuhan}

Data keseragaman pertumbuhan diamati pada hari ke-30 setelah semai. Berdasarkan data pengamatan keseragaman pertumbuhan, diperoleh bahwa dengan perlakuan tingkat naungan $100 \%$ (N3) menunjukkan persentase keseragaman pertumbuhan tertinggi $88,75 \%$, diikuti perlakuan $\mathrm{N} 2$ yaitu $75 \%$ dan tanpa naungan hanya $11.25 \%$. Hasil penelitian pengaruh tingkat naugan terhadap keseragaman pertumbuhan dapat dilihat pada Tabel 6 .

Keseragaman pertumbuhan kecambahan biji kopi robusta yang tinggi di bawah naungan 100\% diduga disebabkan oleh moderasi suhu yang sesuai, intensitas cahaya, kelembaban dan aerasi yang mengakibatkan penguapan air yang lebih sedikit dari tanah, seperti yang dikemukakan oleh [13].

Tabel 6. Pengaruh Tingkat Naungan terhadap Keseragaman Pertumbuhan (\%)

\begin{tabular}{lc}
\hline Tingkat Naungan & $\begin{array}{c}\text { Keseragaman } \\
\text { Pertumbuhan }(\%)\end{array}$ \\
\cline { 2 - 2 } Tanpa Naungan (N1) & 11.25 \\
Tingkat Naungan 75\%(N2) & 75 \\
Tingkat Naungan $100 \%(\mathrm{~N} 3)$ & 88.75 \\
\hline
\end{tabular}

\section{KESIMPULAN}

Perlakuan naungan $100 \%$ pada persemaian benih kopi robusta memberikan persentase perkecambahan (\%), tinggi kecambah, panjang akar, lama hari berkecambah, persentase keseragaman pertumbuhan, dan indeks vigor dengan nilai tertinggi dibanding perlakuan lainnya, dimana tinggi kecambah berbeda nyata pada setiap perlakuannya.

\section{DAFTAR PUSTAKA}

[1] Rahardjo P. 2012. Panduan Budidaya dan Pengolahan Kopi Arabika dan Robusta. Jakarta: Penebar Swadaya

[2] Pusat Data Dan Sistem Informasi. 2020. "Outook Kopi Komoditas Pertanian Subsektor Perkebunan). Jakarta : Kementerian Pertanian

[3] Anteneh, Muradian, R and Ruben, R. 2015. Impact of multiple certification on smallholder coffee farmers' livehoods :Evidence from southern Ethiopia. Research Gate

[4] Arief, MC W, Tarigan, Tarigan, Saragih, R, Lubis, I dan Rahmadani, F. 2011. Panduan Sekolah Lapang Budidaya Kopi Konservasi, Berbagi Pengalaman dari Kabupaten Dairi Provinsi Sumatra Utara. Conservation International. Jakarta

[5] Wayan, W. 2017. Zat Pengatur Tumbuh Giberelin dan Sitokinin. Prodi Agroekoteknologi Fakultas Pertanian Univ.Udayana,Bali

[6] Sutopo L. 2012. Teknologi Benih. Edisi Revisi. Rajawali Pers. Jakarta

[7] Dishna, S. 2000. Water Klasrifikasi menggunakan Moringaoleifera. Gate Informasi Service, schborn, Jerman. http: //www.gtz.de/gate/gateid.afp.

[8] Salisbury FB, Ross CW. 1995. Plant Physiologi $4^{\text {th }}$ Edition. Bandung (ID): Penerbit ITB. 173 hal

[9] Da Silva EAA, Toorop PE, Jaap Nijsse, B ewley JD, Hilhorst HWM. 2005. Eksogen Giberelin menghambat kopi (Coffea arabika cv.Rubi) benih berke cambah dan menyebabkan sel mati di embrio. J. Eks. Bot. 56:1029-1038

[10] Da Silva, EAA. 2002. Perkecambahan Biji Kopi (Coffea arabia cv. Rubi): mekanisme dan regulasi. Disertasi. Wageningen: Universitas Pertanian.

[11] Hilhorst HWM, Karssen CM. 1992. Benih dormansi dan APK- mina tion: Peran asam absisik dan giberelin dan pentingnya mutan hormon. Regulasi Pertumbuhan Tanaman. 11:225-238

[12] Rena AB, Malavolta E, Rocha M, 
Info Artikel Received : 25 November 2021

Revised : $: 27$ Desember 2021

Accepted

: 28 Desember 2021

Jurnal Agrica Ekstensia

Vol. 15 No. 2 Tahun 2021

p-ISSN

: 1978-5054

Yamada T. 1986. Cultur do cafeeiro -

fatores que afetam a produtividade.

Kentang, Piracicaba

[13] Paulo, S. 2006. Bagaimana dan mengapa untuk mengukur dalam proses perkecambahan. Rev. Bot. 29 (1) 